\title{
Perceived Socio-economic, Socio-ecological and Socio-cultural Impacts of the Caribbean's Tourism Sector
}

\author{
Colmore S. Christian, PhD \\ Associate Professor, Department of Biological and Environmental Sciences, Alabama A\&M \\ University, Normal, ALABAMA 35762. \\ Berneece Herbert, PhD \\ Interim Chair \& Coordinator - General Studies Program, Department of Community \\ Development and Urban Studies, Alabama A\&M University, Normal, ALABAMA 35762.
}

\begin{abstract}
A self-administered questionnaire was administered to participants attending the Caribbean Tourism Organization's 2010 Sustainable Tourism Conference held on Barbados to assess their motivation to attend the conference, their satisfaction with the contribution and impact of region's tourism sector, and the level of involvement of the youth in sector. The results of the analysis point to a strong interest in the annual Sustainable Tourism Conferences. Over $70 \%$ of participants were motivated to attend for the purposes of broadening their tourism knowledge base or for networking. The overall impacts of tourism at the community, national and regional levels seem to be acceptable to participants, but close to $15 \%$ of respondents expressed dissatisfaction. There was concern however about the level of involvement of the youth and the extent to which they benefited from the rewards of the tourism sector. This environment of concern may be an opportune time for the Caribbean Tourism Organization (CTO) to consider mechanisms and strategies to attract and engage more youth to the sector. Indeed, there is a need for enhanced cooperation and coordination among CTO member governments, regional and international organizations, the private sector, and civil society actors, to harness the potential of youth for the benefit of the tourism sector. In this regard a few specific initiatives such as a Youth Tourism Ambassador Program and a Youth Tourism Mentors Program have been proposed. The need for more directed and deliberate investments in training programs targeted at the youth should also be considered. The practical implications of the study are discussed, as well as its limitations and scope for future research.
\end{abstract}

Key words: Caribbean Tourism Organization, youth, tourism, integrated development

\section{INTRODUCTION}

Global tourism, one of the fastest growing industries, has an estimated annual rate of growth of $6.2 \%$. The industry, one of the largest in the world "...equals or even surpasses that of oil exports, food products, or automobiles" (UNWTO, 2012a) with an estimated contribution of 6$7 \%$ of the overall number of direct and indirect jobs worldwide and generating an income of around US\$919 billion in 2011. The forecast for growth in international tourist arrivals is positive in the future (UNWTO, 2012a). Tourism, a top job creator and a lead export sector, especially in the context of developing countries, can play an important role in the achievement of a number of the millennium development goals such as: eradication of poverty, promotion of gender equality, and support of environmental sustainability (UNWTO, 2012b). 
This study focusses on an assessment of the tourism sector in the Caribbean. The term 'Insular Caribbean' has been used to refer to the islands of the Caribbean consisting of the Bahamas, Greater Antilles (Cuba, Dominican Republic, Haiti, Jamaica, and Puerto Rico) and the Lesser Antilles, composed of the smaller islands of the region (Heileman, 2007). There are two economic and political sub-grouping in the Insular Caribbean - Caribbean Community and Common Market (CARICOM) which is comprised of 12 of the countries and the nine countries which make-up the Organization of Eastern Caribbean States (OECS). These countries vary in terms of physical size, political status, and cultural background, yet "...they show several similarities in terms of geography, climate, and colonial history. Furthermore, as small islands, they face similar environmental and socio-economic challenges that are characteristic of Small Island Developing States (SIDS), and which distinguish them from the larger mainland countries" (Heileman, 2007).

The insular Caribbean is the most popular warm weather tourism destination The USA Today (2010) reported that five of the ten top warm weather resorts were located in the insular Caribbean more specifically in Bahamas, Barbados, Dominican Republic, Jamaica, and St. Lucia. The Caribbean region is also considered to be the most tourism dependent region of the world (Nurse, 2007). An analysis of the elements of some of the Caribbean Tourism Organization (CTO) member countries' gross domestic product (GDP) seems to support that conclusion (Table 1). In the case of Antigua and Barbuda, income from tourism accounted for slightly over $40 \%$ of GDP in 2006. In Bahamas and St. Lucia tourism's contribution was over 35\%; with the exception of Haiti and Guyana where the tourism sector's contribution to GDP was in single digits, all other destinations listed in Table 1 were in double digits (Kakazu, 2011).

Table 1: Economic Contribution of the Tourism Sector in Selected CTO Countries (source: Kakazu, 2011).

\begin{tabular}{|l|l|l|l|l|l|l|}
\hline Country & $\begin{array}{l}\text { GDPa } \\
\mathbf{( U S \$} \\
\mathbf{m})\end{array}$ & $\begin{array}{l}\text { Trade } \\
\text { balance } \\
\text { (US\$ m) }\end{array}$ & $\begin{array}{l}\text { Tourism } \\
\text { Income } \\
(\text { US } \mathbf{~ m )}\end{array}$ & $\begin{array}{l}\text { Exports/ } \\
\text { GDP (\%) }\end{array}$ & $\begin{array}{l}\text { Tourism } \\
\text { Income/ } \\
\text { GDP (\%) }\end{array}$ & $\begin{array}{l}\text { Tourism } \\
\text { income } \\
> \\
\text { exports }\end{array}$ \\
\hline Antigua \& Barbuda & 757 & -275 & 301 & 5.1 & 40.1 & + \\
\hline Barbados & 2,627 & -923 & 767 & 9.2 & 28.0 & + \\
\hline Bahamas & 5,260 & -892 & 1,795 & 13.7 & 35.6 & + \\
\hline Belize & 989 & -347 & 156 & 19.7 & 14.6 & - \\
\hline Dominica & 259 & -89 & 51 & 16.9 & 18.3 & + \\
\hline Dominican Republic & 16,541 & $-2,444$ & 3,110 & 27.2 & 14.5 & - \\
\hline Guyana & 742 & -60 & 39 & 68.7 & 7.8 & - \\
\hline Grenada & 439 & -198 & 104 & 13.0 & 22.4 & + \\
\hline Haiti & 2,921 & -841 & 93 & 8.7 & 3.1 & - \\
\hline Jamaica & 8,147 & $-2,435$ & 1,621 & 14.8 & 18.9 & + \\
\hline St. Kitts \& Nevis & 346 & -207 & 61 & 9.6 & 17.2 & + \\
\hline St. Lucia & 693 & -300 & 282 & 6.3 & 37.8 & + \\
\hline St. Vincent & 371 & -162 & 85 & 11.6 & 22.8 & + \\
\hline
\end{tabular}

a GDP means gross domestic product.

$b+$ indicates economies where tourism income is greater than export income.

The insular Caribbean is part of a more expansive geographic area commonly referred to as the 'Wider Caribbean'. UNEP (2013) defines the Wider Caribbean Region (WCR) as the region comprising of the insular and coastal States and Territories with coasts on the Caribbean Sea 
and Gulf of Mexico as well as waters of the Atlantic Ocean adjacent to these States and Territories and includes 28 island and continental countries. Given the social, economic, and cultural contributions of the tourism sector to the WCR, particularly to the island-states of the region, it was considered important to gain a better understanding of the sector from the perspectives of tourism industry stakeholders, hence the basis and rationale for this study of representatives of CTO member states.

Traditionally tourism in the Caribbean has been promoted and marketed focusing on the three Ss - sun, sea, and sand. Over the years this promotion and marketing strategy has been relatively successful and contributed to consistent growth in that sector throughout the decades of the 1980s and 1990s.

Over the last decade and a half, the Caribbean region has gradually sought to rebrand and reposition its tourism product partly because of international trends towards more 'responsible travel and tourism' and in part because of the need to ensure that more direct and lasting benefits accrue to local communities and to national economies. Sustainable tourism generally outperforms traditional tourism. Consequently, the sustainable tourism development framework was embraced by the Caribbean region as the vehicle best suited to facilitate the realization of these desired objectives.

\section{Project Goal and Research Questions}

This paper is a one of the outputs of a larger exploratory study aimed at assessing the challenges, the current state and contribution of the Caribbean's tourism sector through the perspectives of regional tourism technocrats and stakeholders. The specific research questions addressed in this study were:

1. What were the factors/reasons which motivated participants to attend CTO's Sustainable Tourism Conference?

2. How satisfied were participants with the overall contribution and impact (at the community, national and regional levels) of the region's tourism sector?

3. To what extent was the region's youth (18-25 years) engaged/involved in the regional sustainable tourism conference as well as the extent to which the youth benefit from the tourism sector?

4. Is the current framework for preventing, reducing and addressing crimes against tourists adequate?

\section{Conceptual Framework}

This research is anchored in the broad concept of sustainable development as initially advanced in the World Commission report entitled 'Our Common Future'. The goal of sustainable development is to ensure that humanity is able to meet "...the needs of the present without compromising the ability of future generations to meet their own needs" (WCED, 1987). Sustainable tourism development according to Kakazu (2011) should lead “...to management of all resources in such a way that economic, social, and aesthetic needs can be fulfilled while maintaining cultural integrity, essential ecological processes, biological diversity, and life support systems". This philosophy is consistent with Dumaine's (2010) who has stated that "Sustainability is about changing mindsets, beginning with our own. Sustainable tourism isn't about growing tourism - it is about managing existing assets better". Sustainable tourism is about advocacy and involvement. Not selling. It is about a belief system that insists that business must make the world more livable - not less (Dumaine, 2010). 
Very importantly sustainable tourism development should ensure that the improved living standards and overall quality of life aspirations of the host community are addressed while satisfying the expectations of the tourists and the tourism industry (Kakazu, 2011). In the Caribbean, sustainable tourism "... is understood as the optimal use of natural, cultural, social and financial resources for national development on an equitable and self-sustaining basis to provide a unique visitor experience and an improved quality of life through partnerships among government, the private sector and communities" (CTO, 2012b). In the context of this paper sustainable tourism is understood to be three-dimensional namely ecological sustainability, social sustainability, and economic sustainability. Tourism sustainability will be elusive if any of these important dimensions are not adequately and collectively addressed in an integrated manner.

\section{Foundation of Sustainable Tourism in the Caribbean}

A series of six CTO conferences on ecotourism held during 1991-1996 served as a precursor to the current series of Sustainable Tourism Conferences (CTO, 2012). In 1997 CTO held its first Sustainable Tourism Conference (STC) on the island of Dominica. Overall, STC has been held annually with the exception of 2001, 2002, 2008, and 2009. Dominica, commonly referred to as 'The Nature Island of the Caribbean' was considered ideal to host such a conference because of the island's rich flora and fauna (terrestrial, aquatic and marine), its picturesque landscapes, its interesting geological formations and associated boiling lake and sulfur springs, as well as its relatively large indigenous population of Caribs. Generally, these Sustainable Tourism Conferences have been held in countries/islands which have either demonstrated or are in the process of embracing a relatively strong environmental ethic (Table 2). STC is part of the information dissemination and regional awareness component of CTO's sustainable tourism strategy. Generally, STC “... looks at how member states can design and implement sustainable tourism policies and programs, offering a regional forum for information exchange on the successes and pitfalls of national, regional and international initiatives" (CTO, 2012c). Delegates to STC including media representatives have the opportunity to participate in "...seminars, workshops and study tours aimed at setting the foundation on which to develop a world class sustainable tourism product in the region and tackle common sustainability issues in the travel industry" (CTO, 2012c). There is a strong economic motivation for consideration of sustainable tourism as a regional strategy. For example, the motivation that sustainable travelers are much more economically beneficial than cruise ship passengers or all-inclusive guests.

Table 2: Host Countries of CTO's Annual Sustainable Tourism Conferences since 1997 (Sources: include CTO websites, newspaper reports, and personal communication with CTO Secretariat).

\begin{tabular}{|c|c|c|}
\hline Year \& SCT-\# & Country & Environmental Strengths and Natural/Cultural Assets \\
\hline 1997 - STC1 & Dominica & $\begin{array}{l}\text { - Rich terrestrial, aquatic, and marine flora and } \\
\text { fauna; } \\
\text { - } \\
\text { Protected areas network and strong environmental } \\
\text { legislation; } \\
\text { - Relatively large population of indigenous Caribs. }\end{array}$ \\
\hline 1998 - STC2 & Trinidad & $\begin{array}{l}\text { Home to the world renowned Caroni Swamp and } \\
\text { its Scarlet Ibis (Eudocimus ruber), the national bird; } \\
\text { - Birth-place of the steel-pan; } \\
\text { - Largest carnival celebrations in the region. }\end{array}$ \\
\hline 1999 - STC3 & Suriname & $\begin{array}{l}\text { Large tracts of rain forests, savannas, coastal } \\
\text { swamps; }\end{array}$ \\
\hline
\end{tabular}




\begin{tabular}{|c|c|c|}
\hline & & $\begin{array}{l}\text { - Different indigenous and ethnic groups; } \\
\text { - In 2000, UNESCO designated the Central Suriname } \\
\text { Nature Reserve as a World Heritage site. }\end{array}$ \\
\hline $2000-$ STC4 & Guyana & $\begin{array}{l}\text { - Rich biodiversity and exquisite natural landscapes; } \\
\text { - Kaieteur Falls - one of the world's natural } \\
\text { - } \quad \text { Ponders; } \\
\text { - Presence of different indigenous ethnic groups. }\end{array}$ \\
\hline $2003-$ STC5 & St. Kitts/Nevis & $\begin{array}{l}\text { - A smoldering volcano and its steaming crater floor; } \\
\text { - Fort Brimstone, World Heritage Site. }\end{array}$ \\
\hline 2004 - STC6 & Cuba & $\begin{array}{l}\text { Very rich music, the most commonly known } \\
\text { expression of culture; } \\
\text { - Has one of the largest reservoirs for nesting } \\
\text { flamingos. }\end{array}$ \\
\hline 2005 - STC7 & Tobago & $\begin{array}{l}\text { - Home to the famous Buccoo Reef; } \\
\text { - Home to } 220 \text { bird species including the turkey-like } \\
\text { Chachalaca, the national bird; } \\
\text { - The endemic Bird-of-Paradise. }\end{array}$ \\
\hline 2006 - STC8 & Puerto Rico & $\begin{array}{l}\text { - Home to the endemic, bright green, and flesh- } \\
\text { colored bill Puerto Rican parrot (Amazona vittata); } \\
\text { Guánica's dry forest is unique and has been } \\
\text { declared an International Biosphere Reserve by } \\
\text { UNESCO. }\end{array}$ \\
\hline 2007 - STC9 & Cayman Islands & $\begin{array}{l}\text { - Two endemic subspecies of parrots: Cayman Brac Parrot } \\
\text { (Amazona leucocephala hesterna), and Grand Cayman Parrot } \\
\text { (Amazona leucocephala caymanensis); } \\
\text { Critically endangered Blue Iguana (Cyclura lewisi), } \\
\text { which is endemic to Grand Cayman }\end{array}$ \\
\hline 2008 -STC10 & $\begin{array}{l}\text { Turks and } \\
\text { Caicos }\end{array}$ & - $\quad$ Has large number of protected areas; \\
\hline $2010-$ STC11 & Barbados & $\begin{array}{l}\text { - Large expanse of white sandy beaches and rich } \\
\text { marine life; } \\
\text { - Birth place of the annual 'crop over festival'. }\end{array}$ \\
\hline 2011 - STC12 & Bermuda & $\begin{array}{l}\text { - Home to the Bermuda Petrel (Pterodroma cahow); } \\
\text { - } 15 \text { endemics among the island's } 165 \text { native plants; }\end{array}$ \\
\hline $2012-$ STC13 & Guyana & $\begin{array}{l}\text { - } \quad \text { Rich biodiversity and exquisite natural landscapes; } \\
\text { - Kaieteur Falls - one of the world's natural } \\
\text { wonders; } \\
\text { - Presence of different indigenous ethnic groups. }\end{array}$ \\
\hline $2013-$ STC14 & Trinidad & $\begin{array}{l}\text { Home to the world renowned Caroni Swamp and } \\
\text { its Scarlet Ibis (Eudocimus ruber), the national bird; } \\
\text { - Birth-place of the steel-pan; } \\
\text { - Largest carnival celebrations in the region. }\end{array}$ \\
\hline
\end{tabular}

\section{MATERIALS AND METHODS}

The CTO operates in the wider Caribbean region. The broad geographic boundaries of CTO member countries currently extend from Venezuela and Trinidad and Tobago in the south to Bahamas in the north, the Central American nations of Belize and Cancun/Cozumel (Mexico) to the west and the Eastern Caribbean island of Barbados to the east (CTO, 2012a; Figure 1). Whereas the independent island-nations (Figure 1) are members of the CTO several of the 
dependencies or overseas territories (e.g. Bermuda, Turks and Caicos, Virgins Islands, Puerto Rico, Guadeloupe, Martinique, St. Eustatius, etc.) of other nations are affiliated to the CTO. Not all the mainland countries identified in Figure 1 are members of the CTO. While governments and quasi-government agencies dominate the membership of CTO, the organization is open to private sector tourism-related entities such as the Miami-based Florida Caribbean Cruise Association (FCCA), tourism industries (e.g. accommodation, transportation, etc.), tourism service providers, ground tour operators, and relevant regional organizations such as the Caribbean Community (CARICOM), Caribbean Development Bank (CDB), and University of the West Indies (UWI), among others.

\section{Synopsis of region's historical background and political environment}

Most of the island states which make-up the CTO are former British, Dutch or French colonies. During the 15th, 16th and 17th centuries these European powers fought for dominance in the Caribbean because of the capacity of these islands to serve as a reliable source of raw material such as sugar, cocoa, limes, and spices to support the industrial thrust of Europe at that time. During that era these competing European powers in the Region tried to impose their religious and cultural norms on enslaved inhabitants and the indigenous populations.

Many of the former British colonies in the Caribbean opted for independence starting in the 1960s. These independent countries chose to pattern their system of government on the Westminster model and retained their membership within the British Commonwealth of Nations. With the exception of the oil-rich countries of Venezuela, the twin-island republic of Trinidad and Tobago, the financial services centers of Turks and Caicos, and the Bahamas, the socio-economic survival of the other CTO member countries are very dependent on the tourism sector.

\section{Data collection}

A four-part self-administered questionnaire consisting of a total of 12 questions was the primary data collection instrument at STC10 held in Barbados in 2010. This was supplemented by information gleaned from a review of relevant literature. The first part of the instrument focused on respondents' demographics and background while the second part solicited respondents' views about the 'growth and development of the region's tourism sector, particularly in terms of satisfaction, challenges/options, and the future outlook'. Sections three and four of the instrument sought participants' opinions about the effectiveness and contribution of existing regional tourism-related organizations and agencies to the social, cultural, and economic welfare of the Region and the motivation for individuals' attendance at STC10 respectively. Pre-testing of the survey instrument was limited to a team four persons. Input for strengthening the initial draft survey instrument came from two sources - pre-test results from three Alabama A\&M University graduate students and a field technician, and comments from a fellow researcher. Their inputs helped to inform the final instrument. 


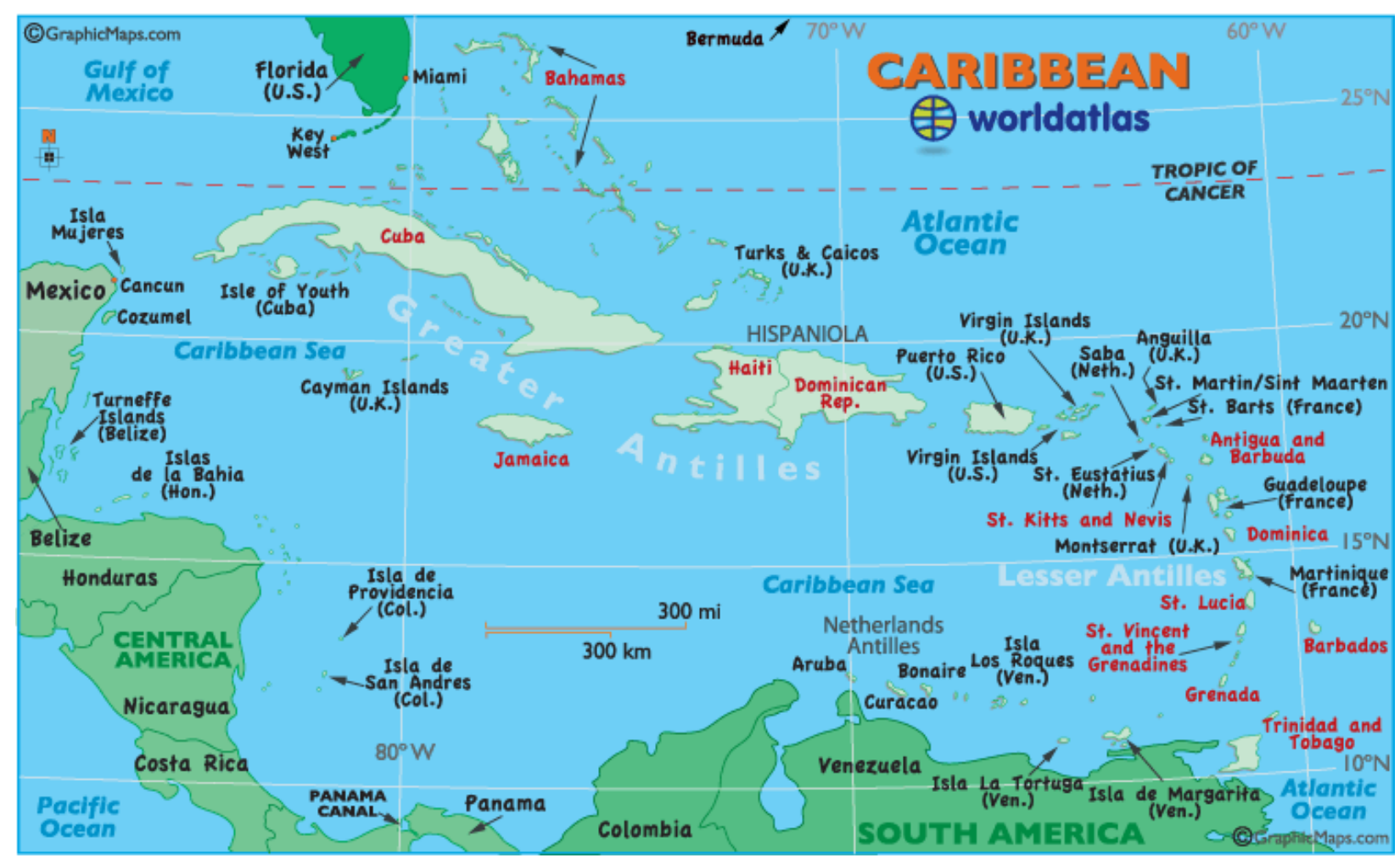

Figure 1: The Geographic Distribution of CTO Member Countries (source: World Atlas, n.a)

Survey procedures and principles advanced by Fowler, Jr. (2009), Rea and Parker (2005), and Vaske, (2008) guided the development of the survey instrument and to a lesser extent the process of administering the questionnaire. Facilitators of the three plenary sessions at STC11 invited and encouraged all participants to complete the questionnaires which had been earlier placed on each seat in the conference hall. On each occasion the facilitators gave a brief rationale for the study. Participants at some of the smaller workshop or special sessions were similarly encouraged and reminded to return completed questionnaires. All the estimated 100 participants at STC11 had an equal opportunity to participate in the study.

A self-administered questionnaire was considered most appropriate at such a conference for three reasons. Firstly, it was assumed that response rate would have been high because of participants' perceived desire to contribute towards sound regional tourism policy formulation and development coupled with their appreciation of the importance of research. The second reason for selecting that approach was because of the fact that the majority of STC participants had completed tertiary education and could therefore read and understand survey questions. Thirdly, participants had the opportunity to complete questionnaire either in between conference sessions or in the convenience of their hotel rooms or at home (for the locals) and return completed questionnaire sometime during the four-day conference. Twenty-seven $(27 \%)$ of participants returned completed questionnaires. Given the exploratory nature of the study the small number of respondents was acceptable considering that there are examples of similar small sample sizes in the literature (Lee, et al, 2008; Altman, 1995). Any follow-up studies, however, would seek to ensure a higher response rate to facilitate hypothesis testing and to enhance more robust analysis.

\section{Data analysis}

Statistical Package for Social Scientists [SPSS] and Microsoft Excel spread sheet data analysis options were used to analyze the data. In the process descriptive statistics were generated, and 
a limited number of correlations were undertaken. Tables and graphs were used to aid in presentation of results.

\section{Demographics of Participants}

\section{RESULTS AND DISCUSSIONS}

The stakeholders who attended SCT11 consisted of a high percentage of mature individuals. Sixty-seven percent of respondents were over 35 years, $18 \%$ were over 50 years old and $45 \%$ were in the 41-50 age range (Figure 2). Persons within the 25-30 year bracket accounted for $11 \%$ of respondents.

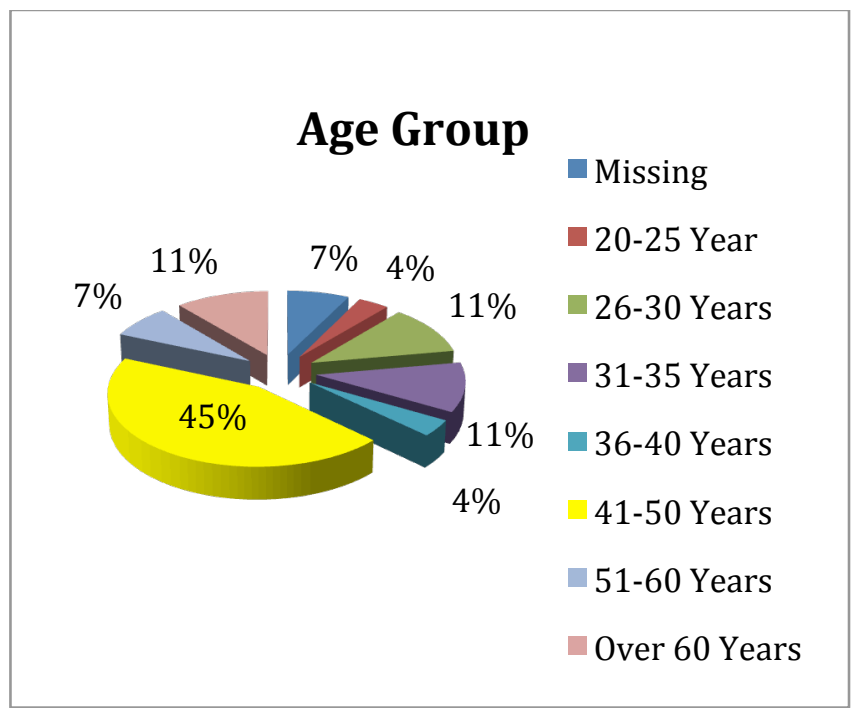

Figure 2: Age distribution of Respondents to Questionnaire administered at SCT11.

It was not surprising that the majority (56\%) of respondents were island representatives. The low level of representatives from Regional Organizations (7.0\%) and International Organizations (4\%) was, however, somewhat disappointing (Figure 3). The low level of representation at SCT10 from the regional and international community may be a reflection of the low level of importance these organizations attach to the development of regional tourism. The time may be opportune for the CTO to embark on the strategic initiative to solicit and galvanize more direct support for and involvement in the tourism sector by regional and internal organizations.

Based on the data analysis $37 \%$ of respondents at SCT11 were government employees whereas $26 \%$ represented the private sector. Interestingly, educators and the non-governmental organization (NGO) community comprised $11 \%$ of participants each (Figure 4). This somewhat moderate level of representation by the NGO and education sectors is encouraging given the critical supporting roles these sectors must in the long-term process of successful adoption and implementation a vibrant sustainable regional tourism strategy. There is need for continuous education and sensitization at all levels of the population - school-aged children and youth, young adults, mature adults and seniors, private sector, public sector, political directorate, and the legal system - about the nexus between the environment, sustainable tourism, national policies, and improved quality of life. Working in tandem with other stakeholders the NGO community can assist in organizing small rural communities in the Region to better assess community-based tourism assets and to source financial resources to develop and benefit from those assets. 


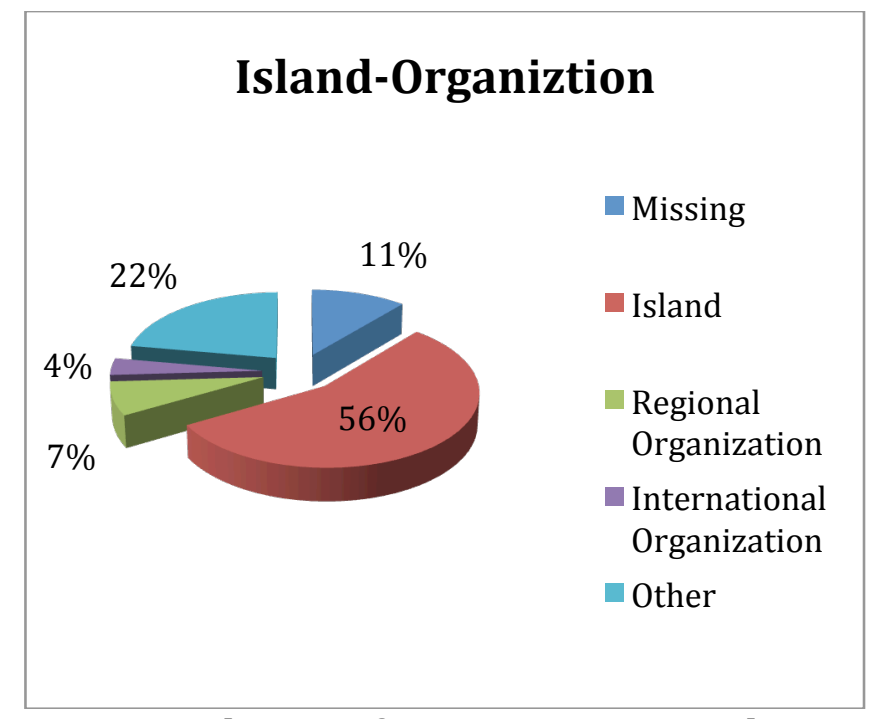

Figure 3: Distribution of Entities Represented at SCT11.

Interestingly, there were no elected officials among the respondents (Figure 4). The authors were aware of the presence of elected officials at STC11. This begs the question then as to the reason(s) why those elected officials who were present did not see the need to participate in the survey.

\section{Motivations and Reasons for attending STC11.}

It is generally expected that individual participants would have different reasons and motivations for attending the Sustainable Tourism Conference. Slightly over half $(51.90 \%)$ of the respondents attended the Conference for the primary purpose of 'expanding their knowledge and information' about the Region's tourism sector. The opportunity for 'networking' was the second most popular (18.5\%) motivation for participating at SCT11 whereas $11.1 \%$ of respondents were present primarily to represent their 'agency/organization' at the Conference.

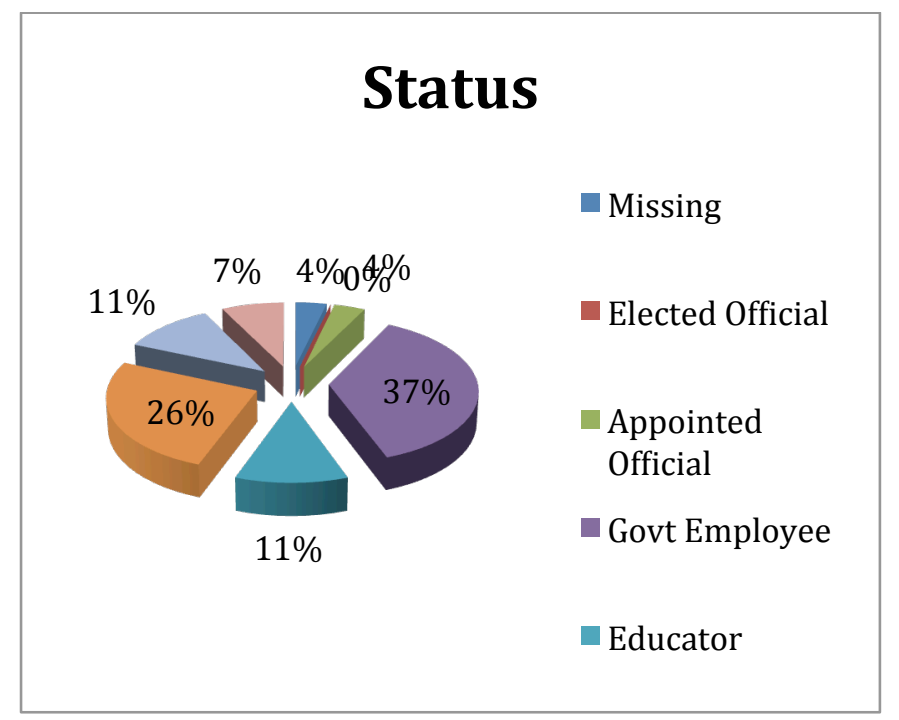

Figure 4: The Employment Status of Survey Respondents at SCT11. 


\section{Purpose for Conference Attendance}

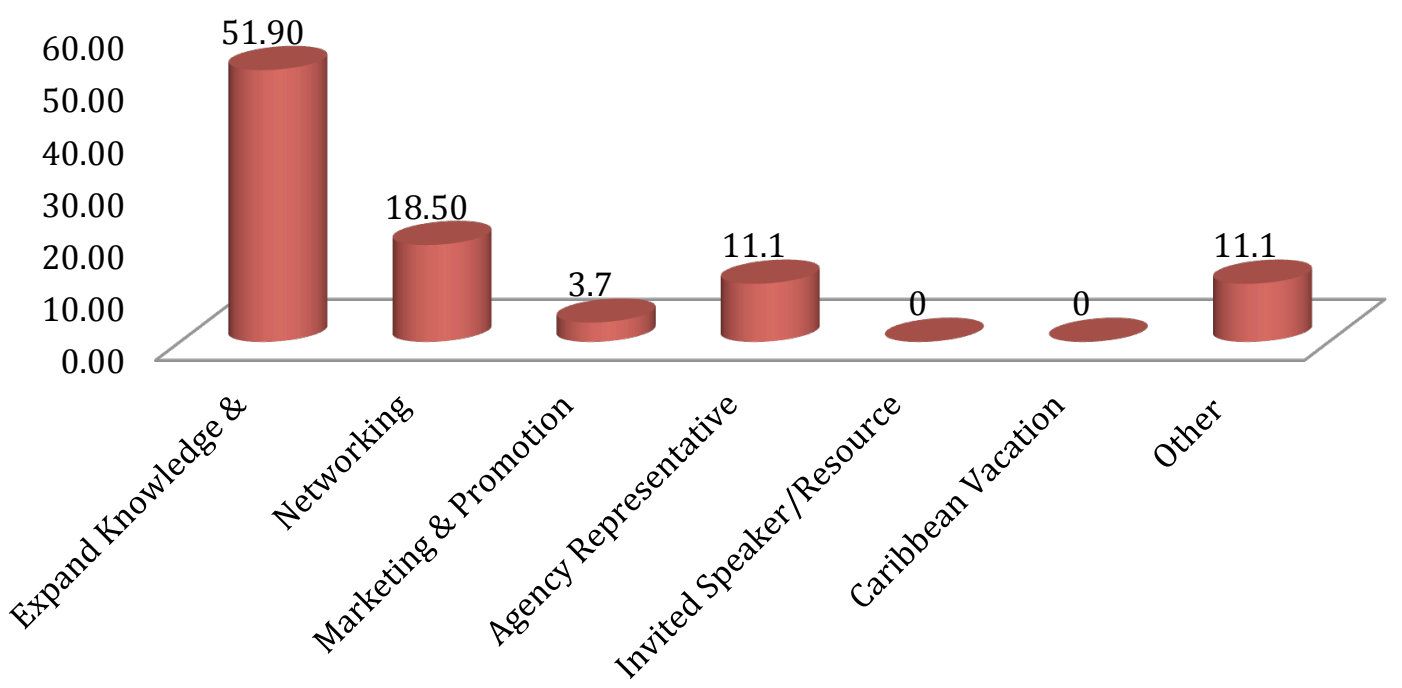

Figure 5: The Motivation of Participants for attending SCT11

\section{Level of Satisfaction with Overall Contribution and Impacts of the Tourism Sector}

There can be no doubt that the tourism sector has made major contributions to the social, economic and cultural development of CTO member states and participating overseas territories during the last three decades. The results of this study indicate that at the national level STC10 participants seem to be either 'very satisfied' $(3.7 \%)$ or satisfied $(55.6 \%)$ with the level of interaction between locals and tourists (Figure 6). The data points to a different picture at the regional level, however. The percentage of 'very satisfied' was the same $(3.7 \%)$ but the 'satisfied' respondents were 15\% lower than at the national level. The level of dissatisfaction at the regional level was higher (11.1\%) compared to the $7.4 \%$ at the national level of dissatisfaction of the level of interaction between locals and visitors (Figure 6). The satisfaction level at the community level was higher than at the national or regional levels (Figure 7). The percentage of respondents who were 'satisfied' with the contribution of tourism at the local community level was $40.7 \%$, percentage of 'very satisfied' was $7.4 \%$ and percentage of 'dissatisfied' respondents was $14.8 \%$. 


\section{National Level - Interaction between Locals \& Visitors}

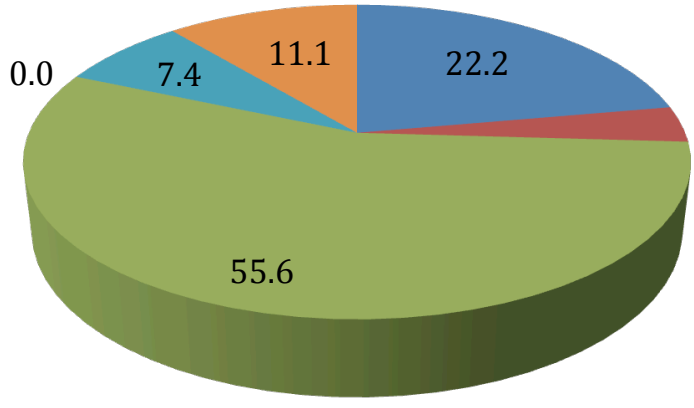

$$
\begin{aligned}
& \text { Missing } \\
& \text { Very Satisfied } \\
& \text { Satisfied } \\
& \text { Very Dissatisfied } \\
& - \text { Dissatisfied } \\
& \text { No Opinion }
\end{aligned}
$$

Figure 6: Level of Satisfaction with the level of interaction between Locals and Visitors at the National Level.

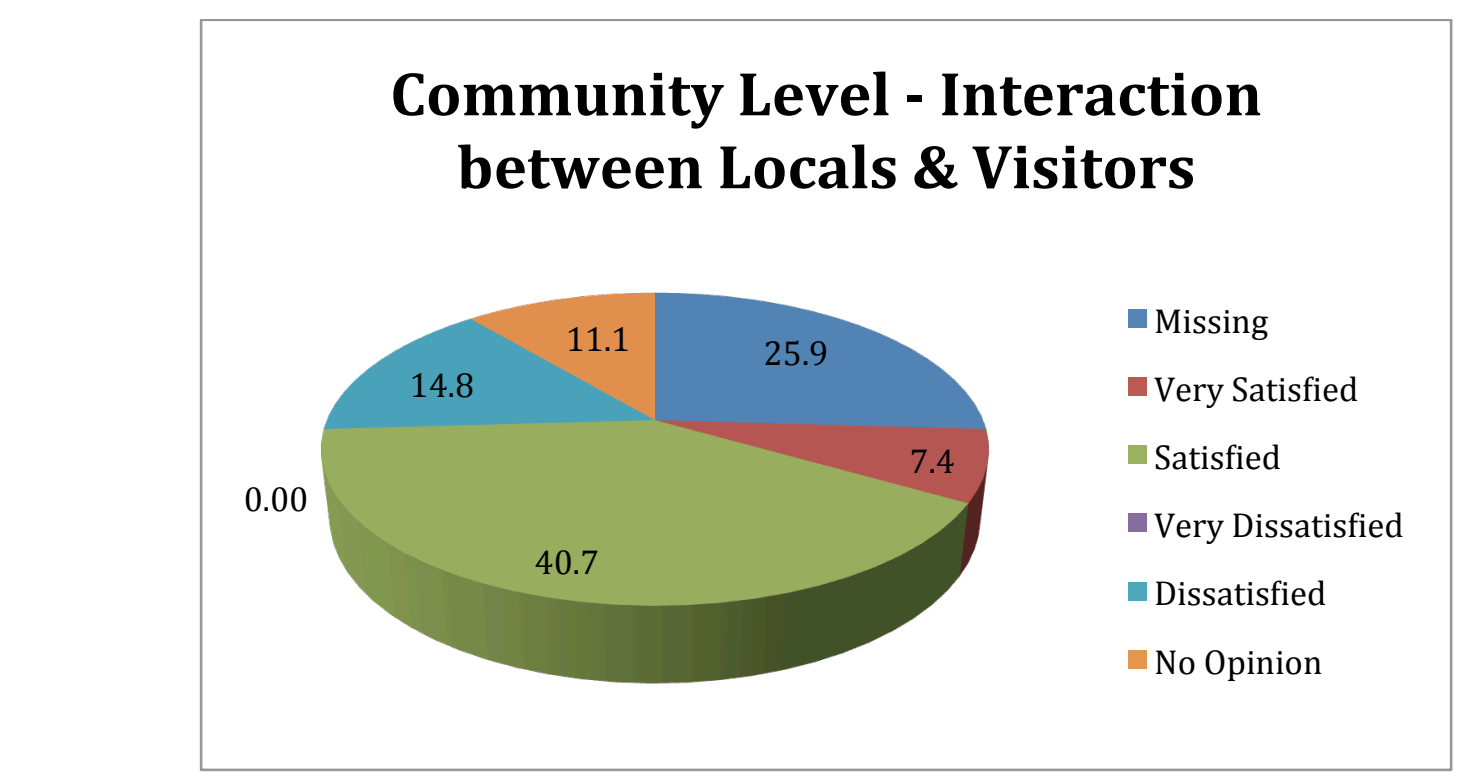

Figure 7: Level of Satisfaction with the level of interaction between Locals and Visitors at the Community Level.

STC11 participants in a large measure seem satisfied with the positive contribution and impact of the regional tourism sector. At the national level $11.1 \%$ were 'very satisfied', $44.4 \%$ were 'satisfied' whereas $11.1 \%$ and $7.4 \%$ of respondents were either 'dissatisfied' or 'very dissatified' respectively with the contribution of tourism towards infrastrucre enhancment (Figure 8). 


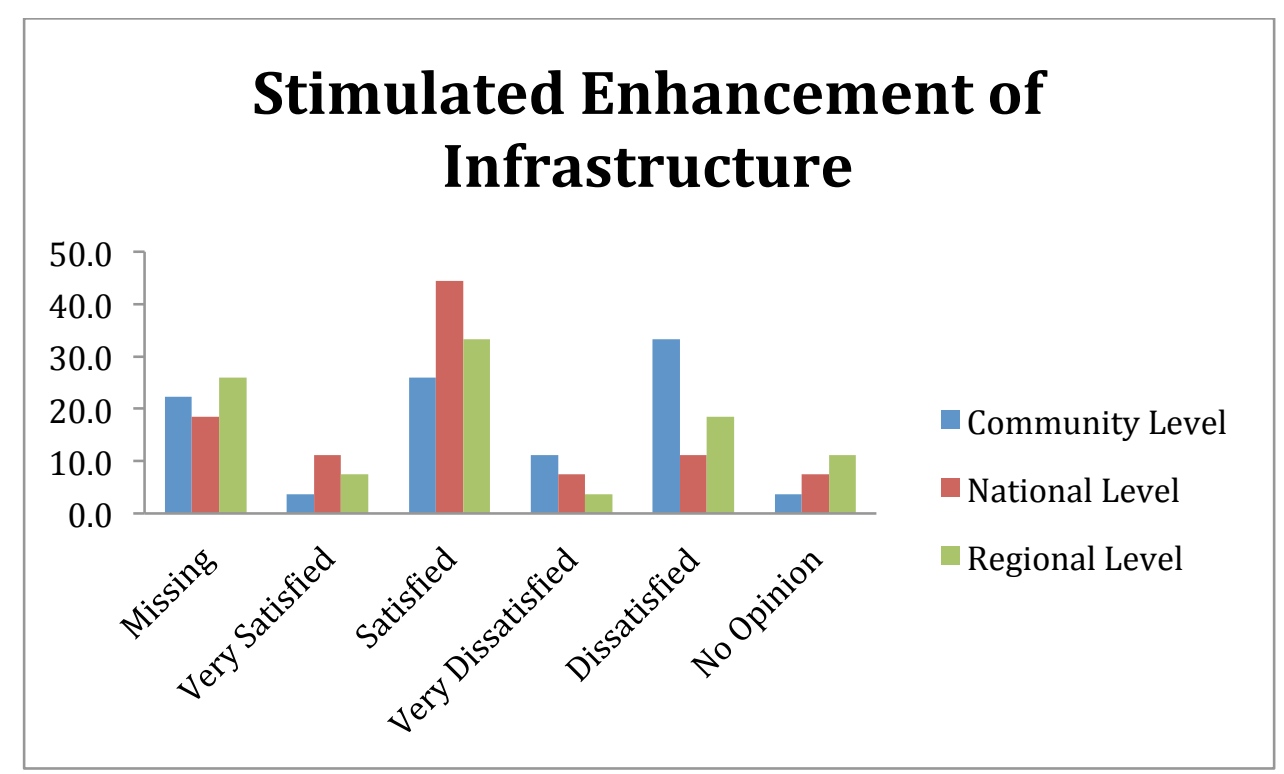

Figure 8: Impact of Regional Tourism on Infrastructural Development

\section{Youth Participation at STC11 and Extent to which the Tourism Sector Benefits the Youth} Young people play many important roles in global tourism. These roles include: (a) constituting a significant proportion of current travel markets, (b) accounting for a considerable number of the people who work in tourism and (c) representing the future of tourism. Thus, understanding the impact of tourism on the youth is important not only for the current management of the tourism sector but also for developing insights into what tourism might be like in the future (Modul Vienna University, 2012). Yet the youth, i.e. those in the 1825 age range was poorly represented at the conference. Only four percent of respondents were under 25 years old.

At the national level only $3.7 \%$ and $18.5 \%$ of the respondents were 'very satisfied' or 'satisfied' with the strategies implemented to promote youth involvement in the tourism sector respectively. A high percentage (37.0\%) of respondents was 'dissatisfied' with youth involvement strategies. This level of dissatisfaction is also reflected at the community and regional levels (Figure 9).

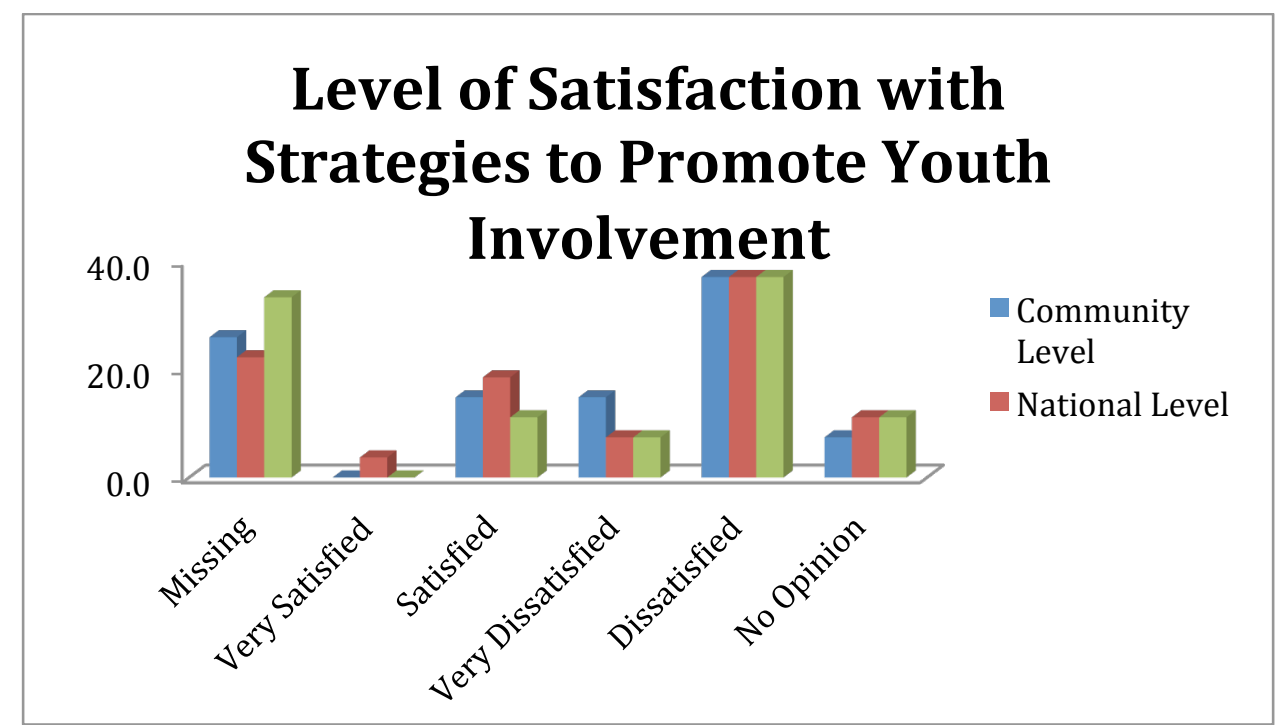

Figure 9: Reflection of Strategies which Promote Youth Involvement 
The private sector can make an important contribution towards youth engagement in sustainable tourism development. Cohan (2009) reported on a successful approach being pioneered by Sandals Beaches Resorts whereby each resort is mandated to adopt a community in close proximity of the Resort. Through this initiative several programs "... targeted towards at-risk youth, including mentorships, youth social clubs, safe sex programs, and community policing..." have been implemented by Sandals Beaches Resorts in places such as Montego Bay, Jamaica (Cohan, 2009). This model can be emulated by other private sector and regional tourism-related agencies/organizations throughout the CTO community.

The analysis points to the limited extent to which the youth currently participates in the CTO's annual Sustainable Tourism Conference and by extension in the Region's tourism development program. The Guyanese media and some concerned professionals noticed and lamented about the pattern of low level of youth participation, a carryover from STC10, at STC13 held in Guyana in 2012 (Jadunauth, 2012; Thomas, 2012). Given the importance of ensuring the involvement and participation of the Region's youth in the tourism sector some of the successful initiatives tried in other regions should be considered. Some of the programs which have been proven to be most effective so far, and which the sustainable tourism industry could specifically focus in the future include: (i) job training in combination with life skills training; (ii) cash transfers to provide incentives for good behavior; (iii) supervised and structured recreation programs; (iv) youth service programs; (v) mentoring programs; (vi) programs that provide youth with job search skills; and (vii) programs that provide youth with entrepreneurship skills" (Cohan, 2009).

Another approach which may be considered is the introduction of a 'Tourism Youth Ambassador Program (TYAP)'. The specifics of this Program are open to further consideration however, some possible elements could include:

a. Selection of one Tourism Youth Ambassador (TYA) by each CTO member state;

b. Ambassadors would serve a three-year term;

c. The process of selecting TYAs would be through National Youth Organizations;

d. CTO in collaboration with its members in host countries should identify a local mentor and possibly a local tourism establishment prepared to offer apprenticeship/employment to TYAs;

e. CTO, in partnership with its members should facilitate TYAs' attendance at future STCs during their term of office. A special TYA forum should be scheduled at STC;

f. Promote the formation of a TYA Alumina Association to build comradery and maintain the interest of TYAs.

Introduction of a 'Tourism Youth Ambassador Program will contribute much to the motivation and sense of responsibility of Youth Ambassadors. The potential model behavior, demonstrated community spirit, and leadership of Tourism Youth Ambassadors could have a positive impact on other community youth.

The introduction of a parallel Youth Tourism Mentors Program (YTMP) would be another possible approach for engaging the Region's youth in the tourism sector. This program could serve as an apprenticeship program for the youth, and help to promote intergenerational relationship building and understanding as well as provide an opportunity for youth employment and participation in tourism. 


\section{Approach to Crime Management in CTO Destinations}

The absence of a strategy and a framework to manage crimes against tourist can destroy the industry. Overall more than half (51.8\%) of respondents were either 'dissatisfied' (37.0\%) or 'very dissatisfied' (14.8\%) with the adequacy of the current legal framework to expedite and facilitate the hearing of crimes against tourists (Figure 10). Only approximately a quarter $(25.9 \%)$ of conference attendees were satisfied with the current legal framework.

Crime was uppermost in the minds of a number of the respondents based on the general comments shared in response to an opened ended question. One person noted that "Crime is escalating in our islands and needs to be addressed' while another person stated that there was "Need for security (first and major concern)". A third individual was of the view that "Crime and over development" should be given urgent attention by regional authorities.

\section{Current Legal Framework for Addressing Crime}

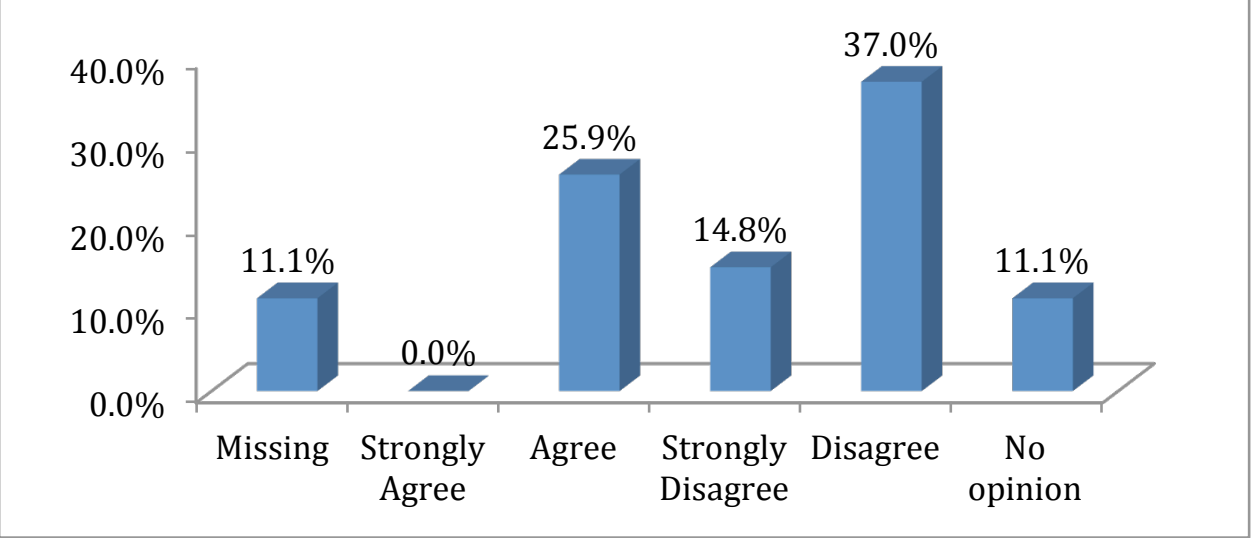

Figure 10: Satisfaction with Current Legal Framework for address Crimes against Visitors

\section{Integrated Approach to Tourism Development}

Tourism destinations can realize maximum social and economic impact of the tourism sector through an integrated approach to development. Ovidiu (2009) reported that, according to the United Nations, integrated development is a "...multidimensional process which involves all sectors of human activity and all factors which have a significant impact on the quality of life and the society as a whole - economic, environmental, physical/spatial and social." Adoption of an integrated development approach, it should be emphasized "... allows [for] an innovative mix of all influence factors in order to increase the well-being of the local community..." both at the microeconomic and macroeconomic levels (Ovidiu, 2009). Integrated development and integrated tourism development are considered as modern methods of developing tourist destinations and therefore ..." should be taken into consideration by local authorities as being working solutions for generating growth in the regions under their control..." (Ovidiu, 2009)

Lack of true inter-sectoral integration has been shown to result in significant 'outward flow' of revenues generated by the tourism sector in many developing countries. In the case of the Caribbean for example as much as $90 \%$ of tourism revenues are either retained in and/or transferred to the source markets to meet cost of a host of tourism-related goods and services such as marketing, promotion, tour organization, transportation, food and beverages, among others. Experience has shown that inter-sectoral integration of the tourism sector at all levels 
(community, national and regional) is one of the proven mechanisms for tourism destinations to be able to capture and retain a higher percentage of revenue generated from tourism sector. Integration will also support sustainable tourism development. Given the forgoing the fact that $62.9 \%$ of respondents (Figure 11) either 'Agreed' or 'Strongly Agreed' with the statement that 'Integrated Tourism Development hasn't been Promoted' should be of concern to and serve as an alarm to Caribbean policy makers and tourism officials.

\section{Integrated Tourism Development hasn't been Promoted}

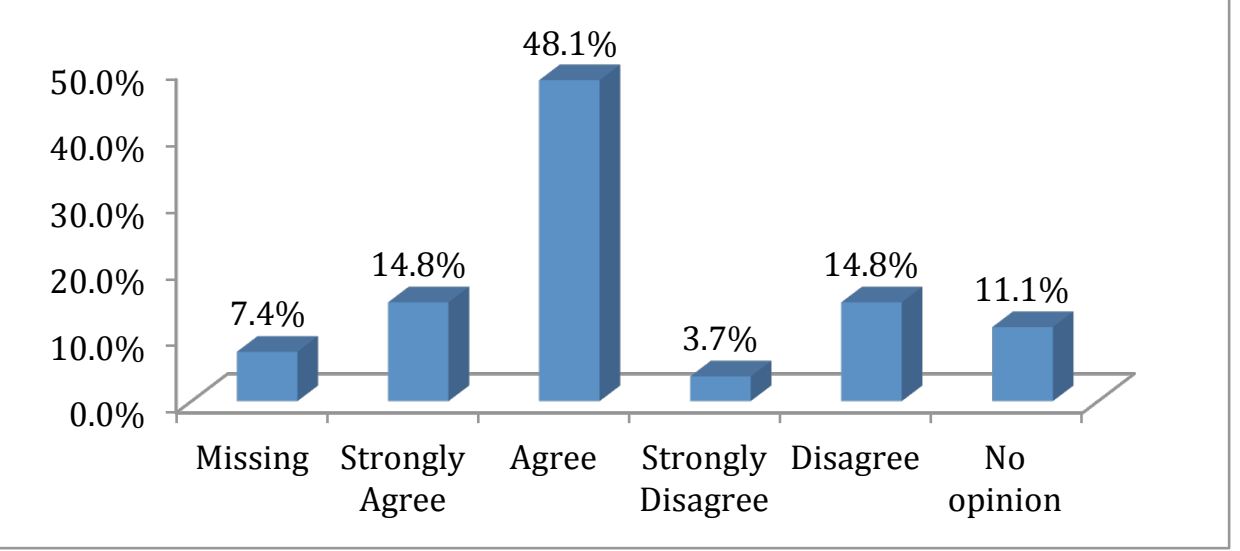

Figure 11: Participants Assessment of level of integrated Tourism Development on the Region.

\section{CONCLUSION}

The authors were very disappointed with the 'non-participation' of the majority STC11 participants in the questionnaire survey. The non-participation of the elected officials who attended STC11 was even of greater concern. It was thought that these elected officials would have taken a greater interest in data collection to support the Region's sustainable tourism development initiatives given the socio-economic importance of tourism to the region.

Notwithstanding, the analysis points to a strong interest in STC. Over 70\% of participants were motivated to attend for the purposes of broadening their tourism knowledge base and for networking. The overall impacts of tourism at the community, national and regional levels seem to be acceptable to participants but close to $15 \%$ of respondents expressed dissatisfaction. However, there was concern about the level of involvement of the youth and the extent to which they benefited from the tourism sector. It may be an opportune time for CTO to consider engaging someone to coordinate and promote youth involvement throughout the CTO geographic space. Furthermore, CTO should provide special student and/or youth STC registration rates as well as negotiate significantly discounted hotel accommodation for students/youths participating in future STCs. Additionally, CTO should seek to encourage each participating member state to include at least one student/youth as part of Government's STC delegation. A similar appeal could be made of large private-sector partners and other regional organizations such as Caribbean Development Bank, CARICOM, and FCCA among others. In short there is a need for enhanced cooperation and coordination among CTO member governments, regional and international organizations, the private sector, and civil society actors, to harness the potential of youth for the benefit of tourism. 
The Caribbean Tourism Organization's advocacy to have tourism as a Caribbean Examination Council (CXC) subject is laudable. This will help to introduce more Caribbean youths to the benefits of the tourism sector to the Region as well as to the range of tourism-related career and investment opportunities. Investments in training programs in entrepreneurship, innovation, information and communication technology, leadership, culinary arts, cultural heritage preservation, natural resource protection, environmental interpretation are a few of the fields likely to engage youth and foster more youth employment in the tourism sector. As Jadunauth (2012) stated "Youth involvement and development need to be seen as an investment, not a cost. And investments imply risks. Consciously and carefully handled, the risks can be minimized".

In spite of the challenges identified in this study and the rising cost of international travel, there is hope for the continued growth of tourism arrivals in CTO member states for many years into the future. This conclusion is based in part on (a) the projected growth in travel and tourism by reputable international agencies such as UNWTO; (b) the strong tourism appeal of the Caribbean; and (c) anticipated higher levels of interests and investments by Regional Governments' given the socio-economic importance of tourism to the Region's future development.

Finally, given the small sample size the authors recognize the potential limitations of this exploratory study. It is not recommended that conclusive policy decisions be made or formulation of proposed strategies is conceived based solely on the results of this study. It must be noted, however, that the findings of the study do provide a very good reference point, in the absence of more comprehensive and reliable data to support the Caribbean's sustainable tourism policy development and strategic visioning.

\section{ACKNOWLEDGEMENT}

The authors are very appreciative of the partial sponsorship and support of the Caribbean Tourism Organization for this study. The partial financial support from the United States Department of Agriculture's McIntire-Stennis initiative (Award \# ALAX-011-M409) is also hereby acknowledged. The constructive comments of peer reviewers were appreciated.

\section{References}

Altman, D. G and Bland, J. M. 1995. Statistics notes: Absence of evidence is not evidence of absence. BMJ 1995; 311 doi: http://dx.doi.org/10.1136/bmj.311.7003.485. BMJ 311:485.

Caribbean Tourism Organization [cited as CTO, 2012]. 2012. Caribbean Conference on Ecotourism/Conference on Sustainable Tourism Development. Sourced at: www.onecaribbean.org/content/files/STCCTC LIST.docx (last accessed June 23, 2012).

Caribbean Tourism Organization [cited as CTO, 2012a]. 2012a. Sourced from:

http://www.onecaribbean.org/aboutus/members/membercountries.aspx (last accessed on May 28, 2012).

Caribbean Tourism Organization [cited as CTO, 2012b]. 2012b. Sourced from:

http://www.onecaribbean.org/programs/ctosustainable/ (last accessed on May 29, 2012).

Caribbean Tourism Organization [cited as CTO, 2012c]. 2012c. STC 14 Scheduled for Trinidad \& Tobago. Sourced from: http://www.caribbeanstc.com/ (last accessed on May 29, 2012).

Cohan, J. 2009. Crime, Violence, At-risk Youth and Responsible Tourism in Latin America and the Caribbean. 'En breve' (Responsible Tourism Series), No. 143 (August 2009), World Bank. Sourced from:

http://siteresources.worldbank.org/INTLACREGTOPURBDEV/Resources/EnBreve143.pdf (last accessed on June 23, 2012).

Dumaine, A. 2010. Remarks to Caribbean Tourism Organization, Bridgetown, Barbados. Sourced from: http://www.onecaribbean.org/content/files/AndyDumaineCTO.pdf (last accessed May, 19, 2012). 
Christian, C.S. \& Herbert, B. (2016). Preceived Socio-Economic, Soio-ecological and Socio-Cultural Impacts of the Caribbean's Tourism Sector. Advances in Social Sciences Research Journal, 3(12) 166-182.

Fowler, Jr., F.J. 2009. Survey Research Methods (4th edition). SAGE Publications, Inc., Thousand Oaks, California, USA.

Heileman, S. 2007. Thematic Report for the Insular Caribbean Sub-region: A discussion paper for the CLME Synthesis Workshop. Sourced from:

http://www.clmeproject.org/CLME\%20Insular\%20Caribbean\%20Thematic\%20Report\%20draft\%2016\%20Feb \%2007[1].pdf (last accessed September 2013).

Jadunauth, T. 2012. Youth absent from tourism conference. Sourced at:

http://www.kaieteurnewsonline.com/2012/07/01/gayle-pollard-shine-in-big-win/ (last accessed June 30, 2012)

Kakazu, H. 2011. Sustainable Island Tourism: the case of Okinawa. Pp: 171-185 in Island Tourism Sustainable Perspectives (Ecotourism Series No. 8), Carlsen, J and R. Butler (Eds.). CAB International, Cambridge, MA.

Lee, S.M., James, L., Buchler, T., Snee, M., Ellis, P., Hackshaw, A. (2008). Phase II trial of thalidomide with chemotherapy and as maintenance therapy for patients with poor prognosis small-cell lung cancer. Lung Cancer, 59(3):364-368

Modul Vienna University. 2012. Youth Tourism. Sourced at: http://www.modul.ac.at/enrichment/youth-tourism (last accessed on June 30, 2012)

NationNews. 2010. Push for Youth in Tourism. Sourced at: http://www.nationnews.com/articles/view/push-foryouth-in-tourism/ (last accessed on June 30, 2012).

Nunkoo, R., Ramkissoon, H. 2011. Residents' Satisfaction with Community Attributes and Support for Tourism. Journal of Hospitality \& Tourism Research, 35 (2):171-190.

Nurse, K. (2007). Development of a Strategic Business Management Model for the Sustainable Development of Heritage Tourism Products in the Caribbean. Caribbean Regional Sustainable Tourism Development Programme, St. Michael, Barbados. Retrieved from http://www.onecaribbean.org/content/files/CRSTDPHeritage\%20Tourism\%20Report.pdf

Ovidiu, T. M. 2009. Integrated Tourism Development. Pp. 32-37 in Ovidius University Annals Economic Sciences Series, Volume XIII in E. C. Spătariu et al (Eds.). Sourced from: http:/www.ovidiusstec.ro/html/anale/ENG/cuprins\%20rezumate/2009\%20vol1.pdf\#page=38

(last accessed June 30, 2012).

Rea, L. M., Parker, R. A. 2005. Designing \& Conducting Survey Research - A Comprehensive Guide (3rd Ed.). Jossey-Bass, San Francisco, CA, USA.

Thomas, M. 2012. Absence of local, youth participants raises eyebrows at tourism conference.

Sourced at: http://www.stabroeknews.com/2012/news/stories/04/17/absence-of-local-youth-participantsraises-eyebrows-at-tourism-conference/ (last accessed June 30, 2012).

Vaske, J. J. 2008. Survey Research and Analysis: Applications in Parks, Recreation and Human Dimensions. Venture Publishing, Inc., State College, Pennsylvania, USA.

United Nations World Tourism Organization [cited as UNWT0). 2012a. Why Tourism. Sourced from: http://www2.unwto.org/en/content/why-tourism (last accessed on May 29, 2012).

United Nations Environmental Program (cited as UNEP). 2013. Regional Seas Program - Wider Caribbean. Sourced from: http://www.unep.org/regionalseas/programmes/unpro/caribbean/ (last accessed September 15, 2013).

United Nations World Tourism Organization [cited as UNWTO, 2012b). 2012b. Tourism and the Millennium Development Goals. Sourced from: http://www.unwto.org/tourism\&mdgsezine/ (last accessed on May 29, 2012).

USA Today. 2010. 10 Great resorts for a warm-weather escape. Sourced from: www.usatoday.com/.../destinations/.../2010-01-28-all-inclusive-resort (last accessed on May 29, 2012).

World Atlas. (n.a.). Map of the Caribbean, Bahamas, Puerto Rico, Cuba, Jamaica, Virgin Islands and more. Sourced from: http://www.worldatlas.com/webimage/countrys/carib.htm (last accessed on June 23, 2012).

World Commission on Environment and Development [cited as WCED). 1987. Our Common Future. Oxford University Press, New York, USA. 